\title{
Heavy Metal Pollution Index of Surface Water and Groundwater Around Tongon Mine (Côte d'Ivoire)
}

\author{
Kagbagnan Kone ${ }^{1}$, Kouakou Adjoumani Rodrigue ${ }^{2, ~ *}$, Konan Edmond Kouassi ${ }^{2}$, Kopoin Adouby ${ }^{1}$ \\ ${ }^{1}$ Laboratoire Des Procédés Industriels de Synthèse de L'environnement et Des Energies Nouvelles, Institut National Polytechniques Félix \\ Houphouët Boigny, Yamoussoukro, Côte d'Ivoire \\ ${ }^{2}$ Laboratoire de Thermodynamique et Physico-chimie du Milieu UFR Sciences Fondamentales et Appliquées, Université Nangui Abrogoua, \\ Abidjan, Côte d'Ivoire
}

Email address:

adjoumanro@gmail.com (K. A. Rodrigue)

${ }^{*}$ Corresponding author

\section{To cite this article:}

Kagbagnan Kone, Kouakou Adjoumani Rodrigue, Konan Edmond Kouassi, Kopoin Adouby. Heavy Metal Pollution Index of Surface Water and Groundwater Around Tongon Mine (Côte d'Ivoire). International Journal of Environmental Monitoring and Analysis.

Vol. 7, No. 5, 2019, pp. 103-111. doi: 10.11648/j.ijema.20190705.12

Received: October 1, 2019; Accepted: October 28, 2019; Published: November 12, 2019

\begin{abstract}
Water is a valued resource, which is increasingly being threatened by mining activity. Monitoring of surface water and groundwater quality around gold mine is essential in terms of heavy metals and toxic substances. The northern zone of Côte d'Ivoire where located Tongon is a highly mineralised zone, with extensive mining of gold. The quality of water resources in this region may be affected by the activity of the Tongon mine, which is the main gold mine in the region. The objectives of this study were to determine the concentration of heavy metals and the Heavy Metal Pollution Index (HPI) in surface water and groundwater around Tongon mine. The concentrations of $\mathrm{As}, \mathrm{Zn}, \mathrm{Pb}, \mathrm{Cd}, \mathrm{Cr}, \mathrm{Cu}$, and $\mathrm{Mn}$ have been evaluated at 21 surface water and 16 groundwater sampling stations. The concentration of these metals were analysed using Inductively Coupled Plasma Mass Spectrometry (ICP-MS) for heavy metal pollution indexing. The concentrations of $\mathrm{As}, \mathrm{Pb}$, $\mathrm{Cr}, \mathrm{Cu}$ and $\mathrm{Mn}$ in surface water were found to be above the highest desirable limit of WHO drinking water standard with mean concentrations of 5.761, 0.016, 0.178, 2.939, and $0.684 \mathrm{mg} / \mathrm{L}$, respectively. Excepted As $(2.95 \mathrm{mg} / \mathrm{L})$ and $\mathrm{Mn}(0.67 \mathrm{mg} / \mathrm{L})$, the metal concentrations in groundwater were well below the permissible limits of WHO drinking water standard. The Heavy Metal Pollution Index was used to evaluate surface water and groundwater quality. The results showed that, in the groundwater samples, HPI values (48.56-72.49) were less than 100, indicating a low-level heavy metal. Concerning surface water, HPI values of Poungbe River are well below the index limit of 100, which suggest that it is generally no contaminated with respect to these metals. The mining activity of Tongon is carried out while protecting water quality against heavy metals. The quality of water resources in the area must be regularly monitored to avoid any dramatic situation.
\end{abstract}

Keywords: Surface Water, Groundwater, Heavy Metal Pollution, Tongon, Gold Mine

\section{Introduction}

Water is vital to the existence of all living organisms [1-4]. However, this valued resource is increasingly being threatened by human population's growth and anthropogenic activities such as mining activity. This is why it is necessary to monitor its quality [1]. Mineral extraction and processing is likely to contribute to the contamination of surface water and groundwater [2]. For example, waste water from nonferrous metal ore mining and smelting, electroplating and other industrial production process is an important contamination source of heavy metal [5]. The heavy metal contamination has the characteristic of the high toxicity, and difficult to degrade, and its migration brings about a broader range of hazards. The research indicated that mining and the smelting activities caused great destruction to the water environment. The heavy metals are difficult to clear away from the natural environment, or even form a secondary pollution [3-5].

Heavy metals can cause adverse effects to human health when their contents exceed the permissible limit in surface 
water [6]. Thus, heavy metals assessment in surface water and groundwater used for drinking purpose is very significance from the human health viewpoint [7]. Heavy metals are usually present in trace amounts in natural water but many of them are toxic even at very low concentration though many of the metals are essential components of the biological system [8]. Heavy metals such as $\mathrm{As}, \mathrm{Pb}, \mathrm{Cd}, \mathrm{Cu}$, $\mathrm{Cr}, \mathrm{Zn}$ and $\mathrm{Mn}$ are highly toxic even in minor quantity. Contaminated surface water when used for irrigation purpose affects soil quality and crop health of the agricultural system [7].

The pollution parameters monitored for the assessment of the quality of any system give an idea of the pollution with reference to these parameters individually. Quality indices are useful to obtain an idea of the synergistic action of all measured pollution parameters. They make it possible to synthesize the various data in the form of a single value. [9]. Quality indices use a set of quality criteria in a reproducible form and compile all pollution parameters in a simple approach, for evaluation of water quality contamination, the Heavy Metal Pollution Index (HPI) was developed [7, 9]. This index is used to assess the level of pollution of water resources by combining several water pollution parameters [7].

In Côte d'Ivoire, Tongon mine is located in north of the country. With an annual production of 8.5 tons of gold per year, the Tongon mine is the largest gold mine in Côte d'Ivoire. Its gold mine reserve is estimated at 3.16 million ounces, or more than 98 tons [10]. Mining in Tongon is an important source of income for Côte d'Ivoire, but it can affect the environment around the mine. In fact, the surface and groundwater around the Tongon gold mine is an important water resource, which is used for crop irrigation and drinking water. Pollution of these waterways would have harmful consequences for populations. Unfortunately, to date, there are no data in the literature on surface and groundwater quality indices around the Tongon gold mine. Thus, it seems essential to assess the quality of these waters in terms of heavy metals. The main objective of this study is to assess the contamination of surface and groundwater around the Tongon gold mine by the Heavy metal Pollution Index (HPI).

\section{Materials and Methods}

\subsection{The Studied Area and Sampling}

Tongon gold mine is located at 9 $9^{\circ} 57^{\prime} 5.76^{\prime \prime} \mathrm{N}$ and $5^{\circ} 42^{\prime} 13.68^{\prime \prime} \mathrm{W}$ (Figure 1). The mean temperature in this region is $27.6^{\circ} \mathrm{C}$ and the annual precipitation for the entire area is reported to be $1400 \mathrm{~mm}$ on average [11]. The sampling network consist of 37 sites, 21 of them surface water and 16 groundwater. The sampling sites are marked by a red point and numbered in Figure 1. Totally, 375 surface water and ground water samples were collected monthly from March 2017 to October 2018. The samples were collected in separate polyethylene bottles. Samples were collected and stored according to the method prescribed in the American Public Health Association manual [12]. A volume of $2 \mathrm{~mL}$ of $65 \% \mathrm{HNO}_{3}$ was added to prevent metal precipitation.

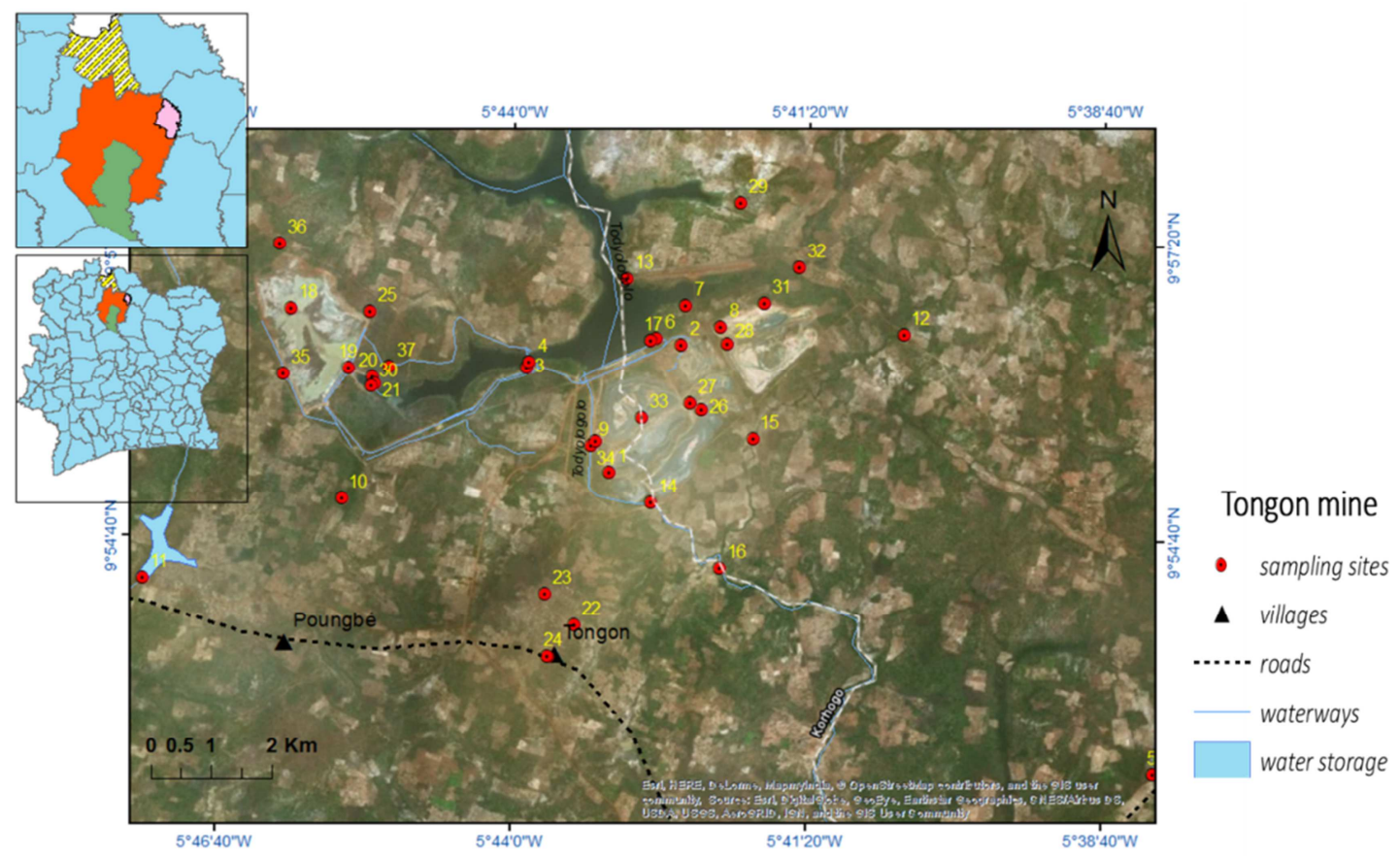

Figure 1. Location and sampling sites around Tongon mine, Côte d'Ivoire.

\subsection{Analytical Methods}

The concentrations of heavy metals were determined by Inductively Couple Plasma Mass Spectroscopy (NexION
2000 ICP-MS, USA), after the samples were concentrated and digested. The minimum limit of detection (LOD) for each heavy metal is resumed in Table 1 . 
Table 1. The limit of detection for $\mathrm{As}, \mathrm{Zn}, \mathrm{Pb}, \mathrm{Cd}, \mathrm{Cr}$, $\mathrm{Cu}$, and $\mathrm{Mn}$.

\begin{tabular}{ll}
\hline Heavy metal & LOD $(\mathbf{m g} / \mathbf{L})$ \\
\hline $\mathrm{As}$ & 0.0005 \\
$\mathrm{Zn}$ & 0.005 \\
$\mathrm{~Pb}$ & 0.0005 \\
$\mathrm{Cd}$ & 0.0001 \\
$\mathrm{Cr}$ & 0.001 \\
$\mathrm{Cu}$ & 0.001 \\
$\mathrm{Mn}$ & 0.002 \\
\hline
\end{tabular}

The proposed HPI was developed by assigning a rating or weightage (Wi) for each selected parameter [7, 9, 13-15]. The rating is a value between zero and one, reflecting the relative importance of individual quality considerations, and can be defined as inversely proportional to the recommended standard (Si) for each parameter. For this study, the highest permissive value for drinking water $(\mathrm{Si})$ and maximum desirable value (Ii) for each parameter were taken according to WHO guidelines (Table 2). The highest permissive value for drinking water $(\mathrm{Si})$ refers to the maximum allowable concentration in drinking water in absence of any alternate water source. The desirable maximum value (Ii) indicates the standard limits for the same parameters in drinking water. The heavy metal pollution index is expressed by equation (1) and (2) as follows [9, 13]:

$$
\mathrm{HPI}=\frac{\sum_{\mathrm{i}=1}^{\mathrm{n}} \mathrm{W}_{\mathrm{i}} \mathrm{Qi}}{\sum_{\mathrm{i}=1}^{\mathrm{n}} \mathrm{W}_{\mathrm{i}}}
$$

Where Qi is the sub index of the ith parameter. Wi is the unit weightage of ith parameter, and $n$ is the number of parameters considered. The sub index (Qi) of the parameter is calculated by

$$
\mathrm{Qi}=\frac{\sum_{\mathrm{i}=1}^{\mathrm{n}} \mathrm{Mi}(-) \mathrm{Ii}}{\mathrm{Si}-\mathrm{Ii}} \times 100
$$

Where $\mathrm{Mi}$ is the monitored value of heavy metal of ith parameter, Ii is the ideal value of ith parameter, and $\mathrm{Si}$ is the standard value of the ith parameter, in $\mathrm{mg} / \mathrm{L}$. The sign (-) indicates the numerical differences of the two values, ignoring the algebraic sign. Generally, the critical pollution index value is 100. HPI index less than 100 indicates that it is a low-level heavy metal and has no adverse health effects. When the value of HPI is equal to 100 , it indicates that the threshold risk and adverse health effects are possible. If the HPI value is more than 100 , water cannot be used for drinking and is unsuitable for consumption [7, 9, 13-15].

Table 2. Applied parameters and constants for calculation of HPI and Qi (according to WHO guidelines).

\begin{tabular}{lllll}
\hline Heavy metal & Permitted value (mg/L) & Unit weightage, Wi & $\begin{array}{l}\text { Desirable maximum value (mg/L) } \\
\text { for drinking water (Ii) }\end{array}$ & $\begin{array}{l}\text { Highest permitted value (mg/L) for } \\
\text { drinking water (Si) }\end{array}$ \\
\hline $\mathrm{As}$ & 0.05 & 0.02 & 0.01 & 0.05 \\
$\mathrm{Zn}$ & 5 & 0.0002 & 3 & 5 \\
$\mathrm{~Pb}$ & 0.015 & 0.7 & 0.01 & 0.1 \\
$\mathrm{Cd}$ & 0.05 & 0.3 & 0.003 & 0.005 \\
$\mathrm{Cr}$ & 0.003 & 0.02 & 0.05 & 0.001 \\
$\mathrm{Cu}$ & 0.05 & 0.001 & 2 & 1 \\
$\mathrm{Mn}$ & 1 & 0.02 & 0.5 & 0.100 \\
\hline
\end{tabular}

Geographic information system (GIS) is widely used for collecting, analysing and presenting all types of spatial and geographical data [15]. The spatial distribution maps were prepared using ArcGIS- 10.2.2 software. The analysis of variance (ANOVA one way) was used to evaluate the difference in metal concentrations between surface water and groundwater sampling sites. Differences were considered significant at $\mathrm{p}$ values $<0.05$. Statistical analyses (mean value, minimum, maximum) were carried out with Statistica 7.1 software.

\section{Results and Discussion}

\subsection{Distribution of Heavy Metals in Water}

The heavy metal concentrations of the surface water and groundwater samples collected in different sampling sites are given in Table 3 and Table 4, respectively.

The metal concentrations $(\mathrm{mg} / \mathrm{L})$ in surface water samples ranged from 0.009 to 53.508 for $\mathrm{As}, 0.005$ to 0.625 for $\mathrm{Zn}$, 0.001 to 0.228 for $\mathrm{Pb},<\mathrm{LOD}$ to 0.00403 for $\mathrm{Cd}, 0.006$ to 2.505 for $\mathrm{Cr}, 0.004$ to 14.275 for $\mathrm{Cu}$, and 0.021 to 10.9 for $\mathrm{Mn}$, respectively (Table 3$)$. The heavy metal concentrations of all surface water samples were $(5.761 \pm 19.099),(0.081 \pm$
$0.252),(0.016 \pm 0.123),(0.0004 \pm 0.0017),(0.178 \pm 0.889)$, $(2.939 \pm 6.751)$ and $(0.684 \pm 2.325) \mathrm{mg} / \mathrm{L}$, for $\mathrm{As}, \mathrm{Zn}, \mathrm{Pb}$, $\mathrm{Cd}, \mathrm{Cr}, \mathrm{Cu}$, and $\mathrm{Mn}$ respectively (Figure 2). Based on these results, it was observed that concentrations of $\mathrm{As}, \mathrm{Pb}, \mathrm{Cr}, \mathrm{Cu}$ and $\mathrm{Mn}$ were above the highest desirable limit of WHO drinking water standard (Table 3). It has been observed that concentrations of heavy metals such as $\mathrm{Cd}$ and $\mathrm{Zn}$ were well below the permissible limits of WHO drinking water standard. The high concentrations of heavy metals in the samples could be explained by the release of heavy metals from mining waste throughout the Tongon mine area. Concerning the groundwater samples (Table 4), the metal concentrations $(\mathrm{mg} / \mathrm{L})$ ranged from 0.002 to 0.263 for As, 0.019 to 0.071 for $\mathrm{Zn}, 0.002$ to 0.034 for $\mathrm{Pb},<\mathrm{LOD}$ to 0.00019 for $\mathrm{Cd}, 0.017$ to 0.040 for $\mathrm{Cr}, 0.005$ to 0.198 for $\mathrm{Cu}$, and 0.008 to 4,025 for $\mathrm{Mn}$. The mean concentrations of all groundwater samples were $(0.036 \pm 0.112),(0.037 \pm 0.048)$, $(0.009 \pm 0.025),(0.000024 \pm 0.000152),(0.021 \pm 0.026)$, $(0.025 \pm 0.117)$ and $(0.662 \pm 1.283) \mathrm{mg} / \mathrm{L}$, for $\mathrm{As}, \mathrm{Zn}, \mathrm{Pb}$, $\mathrm{Cd}, \mathrm{Cr}, \mathrm{Cu}$, and $\mathrm{Mn}$ respectively (Figure 3). Excepted As and $\mathrm{Mn}$, the metal concentrations were well below the permissible limits of WHO drinking water standard (Table 3). 


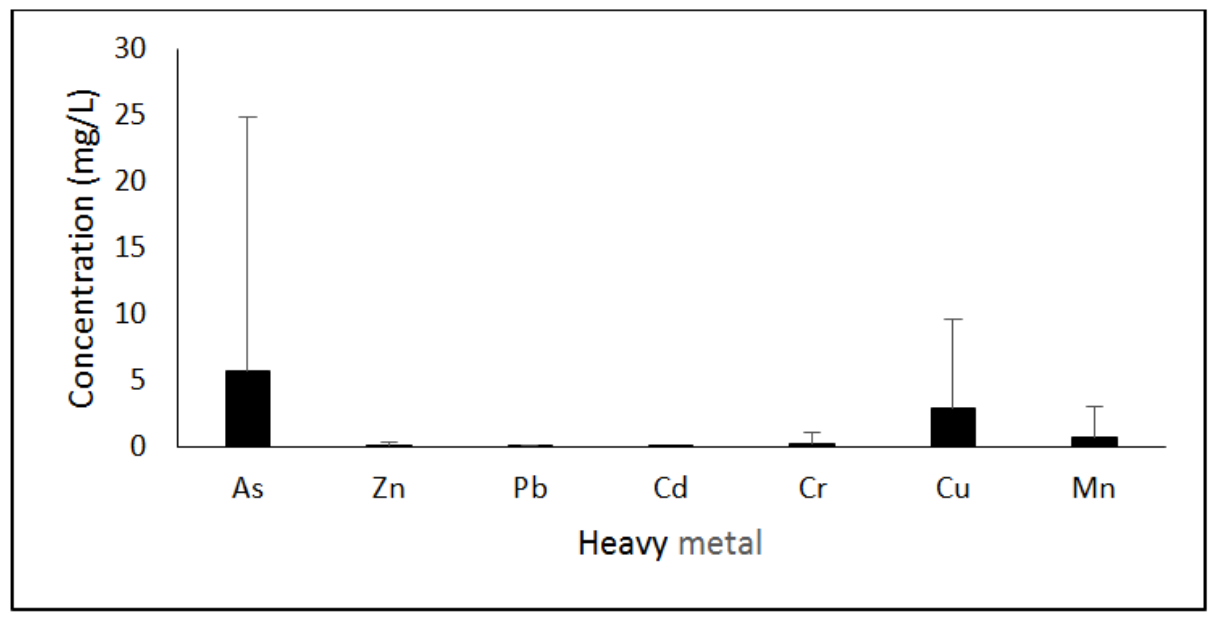

Figure 2. Heavy metal concentrations of all surface water samples.

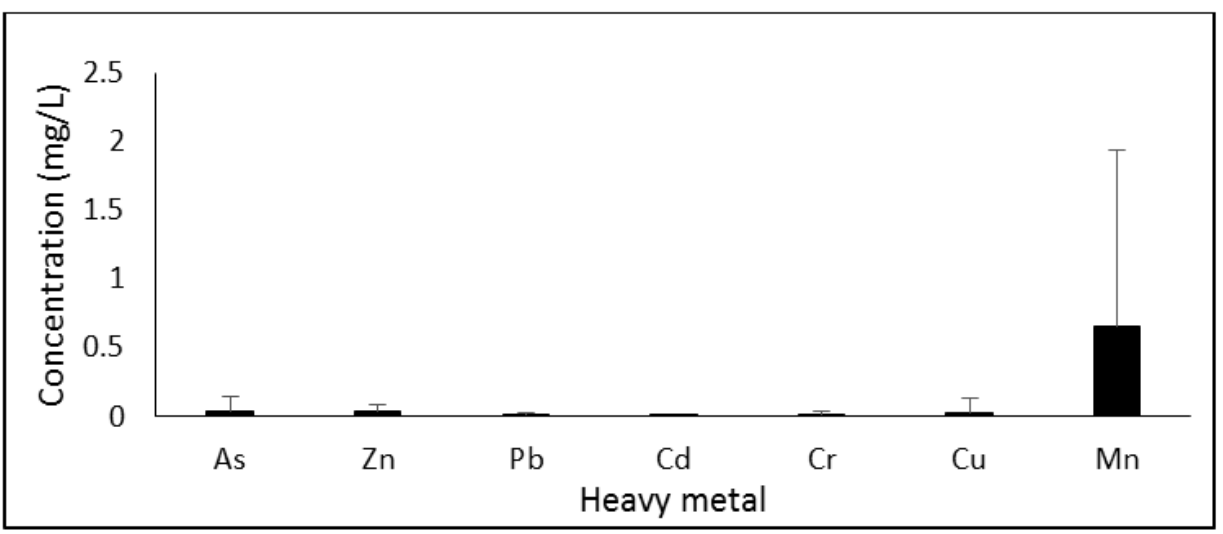

Figure 3. Heavy metal concentrations of all groundwater samples.

Table 3. Concentration of heavy metals in surface water samples ( $\mathrm{mg} / \mathrm{L}$ ).

\begin{tabular}{|c|c|c|c|c|c|c|c|c|c|c|c|c|c|c|}
\hline \multirow{2}{*}{ Sstation } & \multicolumn{2}{|l|}{ As } & \multicolumn{2}{|l|}{ Zn } & \multicolumn{2}{|l|}{$\mathbf{P b}$} & \multicolumn{2}{|l|}{ Cd } & \multicolumn{2}{|l|}{$\mathrm{Cr}$} & \multicolumn{2}{|l|}{$\mathrm{Cu}$} & \multicolumn{2}{|l|}{ Mn } \\
\hline & Mean & SD & Mean & SD & Mean & SD & Mean & SD & Mean & SD & Mean & SD & Mean & SD \\
\hline 1 & 0.068 & 0.054 & 0.060 & 0.035 & 0.002 & 0.002 & 0.00004 & 0.00005 & 0.018 & 0.022 & 0.006 & 0.005 & 0.094 & 0.079 \\
\hline 2 & 3.265 & 3.290 & 0.039 & 0.016 & 0.003 & 0.002 & 0.00020 & 0.00040 & 0.024 & 0.014 & 8.300 & 5.683 & 0.060 & 0.000 \\
\hline 3 & 3.672 & 7.062 & 0.055 & 0.088 & 0.002 & 0.001 & 0.00005 & 0.00015 & 0.028 & 0.033 & 1.085 & 3.283 & 0.353 & 0.349 \\
\hline 4 & 0.055 & 0.129 & 0.042 & 0.033 & 0.003 & 0.004 & 0.00000 & 0.00000 & 0.016 & 0.016 & 0.015 & 0.029 & 0.324 & 0.272 \\
\hline 5 & 0.294 & 0.437 & 0.031 & 0.040 & 0.003 & 0.003 & 0.00014 & 0.00021 & 0.019 & 0.018 & 0.011 & 0.005 & 0.070 & 0.081 \\
\hline 6 & 0.015 & 0.012 & 0.050 & 0.021 & 0.002 & 0.001 & 0.00008 & 0.00010 & 0.037 & 0.005 & 0.011 & 0.006 & 0.068 & 0.043 \\
\hline 7 & 0.032 & 0.021 & 0.042 & 0.021 & 0.003 & 0.002 & 0.00020 & 0.00040 & 0.042 & 0.008 & 0.027 & 0.031 & 0.112 & 0.062 \\
\hline 8 & 0.146 & 0.051 & 0.009 & 0.002 & 0.002 & 0.001 & 0.00002 & 0.00004 & 0.015 & 0.016 & 0.008 & 0.002 & 0.056 & 0.019 \\
\hline 9 & 0.657 & 0.675 & 0.059 & 0.085 & 0.002 & 0.001 & 0.00024 & 0.00032 & 0.035 & 0.048 & 0.018 & 0.032 & 0.074 & 0.096 \\
\hline 10 & 6.650 & 1.066 & 0.005 & 0.004 & 0.001 & 0.001 & 0.00005 & 0.00010 & 0.006 & 0.001 & 0.024 & 0.029 & 10.900 & 0.000 \\
\hline 11 & 0.012 & 0.007 & 0.035 & 0.034 & 0.002 & 0.001 & 0.00000 & 0.00000 & 0.012 & 0.013 & 0.008 & 0.005 & 0.214 & 0.134 \\
\hline 12 & 0.011 & 0.016 & 0.040 & 0.027 & 0.001 & 0.001 & 0.00000 & 0.00000 & 0.012 & 0.017 & 0.004 & 0.001 & 0.920 & 0.000 \\
\hline 13 & 0.009 & 0.017 & 0.029 & 0.025 & 0.001 & 0.001 & 0.00000 & 0.00000 & 0.016 & 0.016 & 0.007 & 0.006 & 0.086 & 0.046 \\
\hline 14 & 0.219 & 0.214 & 0.035 & 0.041 & 0.001 & 0.001 & 0.00017 & 0.00030 & 0.016 & 0.017 & 0.006 & 0.004 & 0.062 & 0.044 \\
\hline 15 & 0.132 & 0.137 & 0.036 & 0.029 & 0.002 & 0.001 & 0.00016 & 0.00029 & 0.016 & 0.017 & 0.007 & 0.005 & 0.217 & 0.128 \\
\hline 16 & 0.106 & 0.095 & 0.041 & 0.056 & 0.002 & 0.001 & 0.00015 & 0.00029 & 0.016 & 0.016 & 0.007 & 0.003 & 0.398 & 0.490 \\
\hline 17 & 0.011 & 0.013 & 0.034 & 0.028 & 0.001 & 0.001 & 0.00004 & 0.00014 & 0.018 & 0.018 & 0.005 & 0.003 & 0.094 & 0.019 \\
\hline 1 & 15.862 & 12.024 & 0.107 & 0.220 & 0.002 & 0.002 & 0.00032 & 0.00058 & 0.036 & 0.024 & 13.539 & 11.008 & 0.030 & 0.021 \\
\hline 19 & 10.800 & 4.525 & 0.007 & 0.000 & 0.009 & 0.012 & 0.00000 & 0.00000 & 0.023 & 0.023 & 14.275 & 8.096 & 0.001 & 0.002 \\
\hline 20 & 9.172 & 8.567 & 0.041 & 0.054 & 0.001 & 0.001 & 0.00022 & 0.00037 & 0.028 & 0.035 & 13.646 & 8.143 & 0.326 & 0.321 \\
\hline 21 & 53.508 & 54.914 & 0.625 & 0.817 & 0.228 & 0.455 & 0.00403 & 0.00596 & 2.505 & 2.711 & 9.526 & 9.420 & 6.718 & 6.086 \\
\hline
\end{tabular}


Table 4. Concentrations of heavy metal in groundwater samples $(\mathrm{mg} / \mathrm{L})$.

\begin{tabular}{|c|c|c|c|c|c|c|c|c|c|c|c|c|c|c|}
\hline \multirow{2}{*}{ Station } & \multicolumn{2}{|l|}{ As } & \multicolumn{2}{|l|}{ Zn } & \multicolumn{2}{|l|}{$\mathbf{P b}$} & \multicolumn{2}{|l|}{ Cd } & \multicolumn{2}{|l|}{$\mathrm{Cr}$} & \multicolumn{2}{|l|}{$\mathrm{Cu}$} & \multicolumn{2}{|l|}{ Mn } \\
\hline & Mean & SD & Mean & SD & Mean & SD & Mean & SD & Mean & SD & Mean & SD & Mean & SD \\
\hline 22 & 0.006 & 0.007 & 0.029 & 0.023 & 0.002 & 0.005 & 0.00002 & 0.00004 & 0.017 & 0.017 & 0.016 & 0.019 & 0.096 & 0.014 \\
\hline 23 & 0.002 & 0.003 & 0.019 & 0.016 & 0.003 & 0.006 & 0.00002 & 0.00006 & 0.017 & 0.017 & 0.009 & 0.009 & 0.113 & 0.033 \\
\hline 24 & 0.003 & 0.003 & 0.023 & 0.017 & 0.002 & 0.001 & 0.00001 & 0.00004 & 0.018 & 0.017 & 0.007 & 0.003 & 0.261 & 0.249 \\
\hline 25 & 0.006 & 0.005 & 0.023 & 0.015 & 0.013 & 0.012 & 0.00002 & 0.00006 & 0.017 & 0.018 & 0.023 & 0.062 & 2.474 & 0.409 \\
\hline 26 & 0.024 & 0.027 & 0.071 & 0.138 & 0.006 & 0.003 & 0.00001 & 0.00003 & 0.034 & 0.020 & 0.009 & 0.008 & 0.075 & 0.080 \\
\hline 28 & 0.263 & 0.291 & 0.034 & 0.029 & 0.034 & 0.078 & 0.00019 & 0.00054 & 0.040 & 0.077 & 0.198 & 0.408 & 1.013 & 0.978 \\
\hline 29 & 0.098 & 0.046 & 0.050 & 0.044 & 0.025 & 0.031 & 0.00001 & 0.00003 & 0.022 & 0.018 & 0.023 & 0.037 & 1.687 & 0.294 \\
\hline 30 & 0.002 & 0.002 & 0.058 & 0.022 & 0.001 & 0.001 & 0.00000 & 0.00000 & 0.018 & 0.017 & 0.009 & 0.006 & 0.008 & 0.008 \\
\hline 3 & 0.025 & 0.007 & 0.045 & 0.034 & 0.008 & 0.004 & 0.00001 & 0.00003 & 0.020 & 0.016 & 0.013 & 0.007 & 0.113 & 0.132 \\
\hline 32 & 0.078 & 0.195 & 0.045 & 0.057 & 0.006 & 0.005 & 0.00003 & 0.00009 & 0.020 & 0.019 & 0.013 & 0.014 & 4.025 & 2.523 \\
\hline 33 & 0.003 & 0.004 & 0.033 & 0.035 & 0.002 & 0.002 & 0.00001 & 0.00000 & 0.018 & 0.018 & 0.007 & 0.006 & 0.014 & 0.011 \\
\hline 34 & 0.009 & 0.019 & 0.030 & 0.039 & 0.003 & 0.003 & 0.00001 & 0.00000 & 0.017 & 0.016 & 0.009 & 0.006 & 0.010 & 0.006 \\
\hline 36 & 0.009 & 0.014 & 0.033 & 0.027 & 0.016 & 0.023 & 0.00002 & 0.00006 & 0.018 & 0.017 & 0.009 & 0.011 & 0.021 & 0.024 \\
\hline 37 & 0.007 & 0.012 & 0.022 & 0.024 & 0.007 & 0.006 & 0.00001 & 0.00001 & 0.017 & 0.017 & 0.006 & 0.003 & 0.065 & 0.153 \\
\hline
\end{tabular}

The analysis of variance was performed using metal data to compare heavy metal concentrations in surface water samples with those in groundwater. It was observed that concentrations of $\mathrm{As}, \mathrm{Zn}, \mathrm{Cd}, \mathrm{Cd}, \mathrm{Cr}$ and $\mathrm{Cu}$ in surface water samples were statistically higher than those in groundwater (Table 5). This difference is due to the absorption of metals by the different components of the soil and sediments such as carbonates, oxides and organic matter.

Table 5. ANOVA test for significance between surface water and groundwater (difference are significant at P<0.05).

\begin{tabular}{|c|c|c|c|c|c|c|c|c|}
\hline & SC & dl & MC & SC & dl & MC & $\mathbf{F}$ & $\mathbf{p}$ \\
\hline As & 3071.370 & 1 & 3071.370 & 69308.85 & 373 & 185.8146 & 16.52922 & 0.000058 \\
\hline $\mathrm{Zn}$ & 0.162 & 1 & 0.162 & 11.45 & 343 & 0.0334 & 4.85819 & 0.028179 \\
\hline $\mathrm{Pb}$ & 0.004 & 1 & 0.004 & 2.97 & 373 & 0.0080 & 0.48765 & 0.485413 \\
\hline $\mathrm{Cd}$ & 0.000 & 1 & 0.000 & 0.00 & 373 & 0.0000 & 6.85664 & 0.009191 \\
\hline $\mathrm{Cr}$ & 2.293 & 1 & 2.293 & 150.47 & 373 & 0.4034 & 5.68437 & 0.017616 \\
\hline $\mathrm{Cu}$ & 796.423 & 1 & 796.423 & 8663.16 & 373 & 23.2256 & 34.29070 & 0.000000 \\
\hline
\end{tabular}

Table 6 gives the reported concentration range of metals in surface water and groundwater by various studies conducted in Cote d'Ivoire. It can be seen that the concentrations of heavy metals reported in the present investigation are below than the high concentration range reported by Bakary et al., and Coulibaly et al $[17,18]$. It is observed that the concentration range of $\mathrm{Zn}, \mathrm{Cd}$ and $\mathrm{Pb}$ are similar to the low concentration range reported by Naminata et al [16].

Table 6. Heavy metal concentrations $(\mathrm{mg} / \mathrm{L})$ reported in Cote d'Ivoire water samples in other studies.

\begin{tabular}{|c|c|c|c|c|c|c|c|c|}
\hline Location & As & Zn & $\mathbf{P b}$ & Cd & $\mathrm{Cr}$ & $\mathbf{C u}$ & Mn & Reference \\
\hline $\begin{array}{l}\text { Surface water and groundwater } \\
\text { water (MBadon) }\end{array}$ & - & $0.03-0.06$ & $0.26-0.86$ & $0.04-0.24$ & - & $0.007-3.93$ & - & {$[16]$} \\
\hline Milliardaires Bay & - & $1.14-4.33$ & $0.31-1.73$ & $0.03-0.17$ & - & $0.04-0.14$ & - & [17] \\
\hline $\begin{array}{l}\text { Surface and ground water around } \\
\text { Tongon mine }\end{array}$ & $\begin{array}{l}<\text { LOD - } \\
13.91\end{array}$ & $0.01-2.63$ & $<\mathrm{LOD}-1.60$ & $<\mathrm{LOD}-0.02$ & $<\mathrm{LOD}-9.00$ & $\begin{array}{l}<\text { LOD - } \\
39.00\end{array}$ & $\begin{array}{l}<\text { LOD - } \\
14.30\end{array}$ & present study \\
\hline
\end{tabular}

A number of significant correlations were obtained in the Study (Table 7). The correlation at 5\% level of significance $(\mathrm{P}<0.05)$ shows significant correlation between the following pairs As and $\mathrm{Zn}, \mathrm{Pb}, \mathrm{Cr}$; $\mathrm{Cd}, \mathrm{Cu}$ and $\mathrm{Mn}$; $\mathrm{Zn}$ and $\mathrm{As}, \mathrm{Pb}, \mathrm{Cd}$, $\mathrm{Cr}$ and $\mathrm{Mn} ; \mathrm{Pb}$ and $\mathrm{As}, \mathrm{Zn}, \mathrm{Cd}, \mathrm{Cr}$, and $\mathrm{Mn} ; \mathrm{Cd}$ and $\mathrm{As}, \mathrm{Zn}$, $\mathrm{Pb}, \mathrm{Cr}$, and $\mathrm{Mn}$; $\mathrm{Cr}$ and $\mathrm{As}, \mathrm{Zn}, \mathrm{Cd}$ and $\mathrm{Mn} ; \mathrm{Mn}$ and $\mathrm{As}, \mathrm{Zn}$, $\mathrm{Cd}$ and $\mathrm{Cr}$. $\mathrm{Cu}$ shows significant correlation with As. Overall the convergent results indicated that the significant correlation was correlated with a common source. The source of these elements is the gold mining activity.
Table 7. Correlation matrix between heavy metals (bold correlations are significant at $\mathrm{P}<0.05$ ).

\begin{tabular}{llllllll}
\hline & As & Zn & Pb & Cd & Cr & Cu & Mn \\
\hline $\mathrm{As}$ & 1,00 & & & & & & \\
$\mathrm{Zn}$ & 0,85 & 1,00 & & & & & \\
$\mathrm{~Pb}$ & 0,48 & 0,47 & 1,00 & & & & \\
$\mathrm{Cd}$ & 0,89 & 0,91 & 0,39 & 1,00 & & & \\
$\mathrm{Cr}$ & 0,88 & 0,90 & 0,48 & 0,99 & 1,00 & & \\
$\mathrm{Cu}$ & 0,39 & 0,03 & 0,01 & 0,05 & 0,05 & 1,00 & \\
$\mathrm{Mn}$ & 0,63 & 0,63 & 0,39 & 0,67 & 0,66 & $-0,01$ & 1,00 \\
\hline
\end{tabular}




\subsection{Heavy Metal Pollution Index}

Mean concentrations of the analysed metals were used to calculate the HPI values. The HPI values of surface water sampling sites ranged from 50.03 to 794.51 (Table 8) Sampling sites $\mathrm{N}^{\circ} 10,18,19,19,20$ and 21 have HPI values higher than the critical HPI threshold value (100). These sampling sites are contaminated. The higher values of HPI may be attributed to the gold mining activity [13]. The water in these sampling sites come from directly of the mine plant, the artificial dam, and the artificial lake, which is created to collect runoff water during rainfall in the mine. It is important to note that the Tongon mine has a water reusing system. This system uses the contaminated surface water in the processes of the mine plant. The sampling site $\mathrm{N}^{\circ} 8$ is located at the site where the mine water is discharged into the environment. The HPI value of the sampling station $\mathrm{N}^{\circ} 8$ was below 100 (Figure 4). It is far below the critical HPI threshold value (Table 8). It indicates that the sampling site $\mathrm{N}^{\circ} 8$ is not contaminated by the heavy metals studied. It shows that the water reusing system in the Tongon mine is operating. It is confirmed by HPI values of the sampling station $\mathrm{N}^{\circ} 12,15$ and 16 which were below 100 . These sampling stations are located at the Poungbe River.

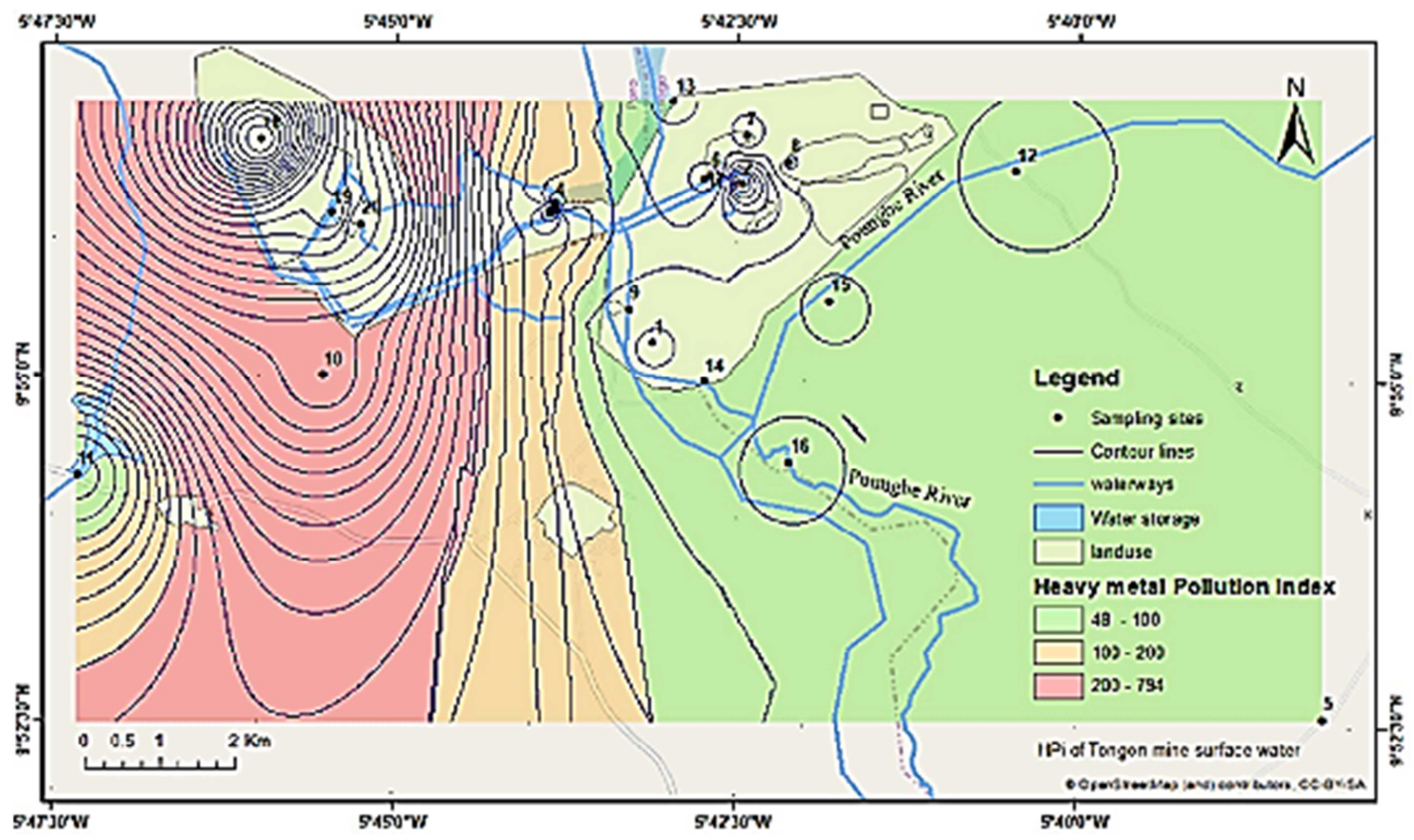

Figure 4. HPI map of surface water around Tongon mine.

Table 8. Heavy metal pollution index of surface water sampling stations.

\begin{tabular}{|c|c|c|c|c|c|c|c|c|}
\hline Station & Qi-As & Qi-Zn & Qi-Pb & Qi-Cd & Qi-Cr & Qi-Cu & Qi-Mn & Wi $\times$ Qi-As \\
\hline 1 & 145.00 & 146.98 & 8.78 & 148.00 & 64.49 & 199.42 & 101.50 & 2.90 \\
\hline 2 & 8137.50 & 148.03 & 7.43 & 140.00 & 53.06 & 630.00 & 110.00 & 162.75 \\
\hline 3 & 9153.85 & 147.25 & 9.07 & 147.31 & 45.37 & 91.53 & 36.79 & 183.08 \\
\hline 4 & 111.58 & 147.88 & 7.72 & 150.00 & 70.17 & 198.47 & 44.08 & 2.23 \\
\hline 5 & 709.75 & 148.44 & 8.18 & 143.13 & 64.03 & 198.95 & 107.50 & 14.20 \\
\hline 6 & 11.88 & 147.50 & 8.67 & 146.25 & 26.02 & 198.88 & 108.13 & 0.24 \\
\hline 7 & 53.75 & 147.91 & 7.89 & 140.00 & 17.35 & 197.33 & 97.00 & 1.08 \\
\hline 9 & 1617.92 & 147.07 & 9.14 & 137.92 & 31.46 & 198.24 & 106.46 & 32.36 \\
\hline 10 & 16600.00 & 149.77 & 9.92 & 147.50 & 90.82 & 197.58 & 2600.00 & 332.00 \\
\hline 11 & 4.09 & 148.25 & 8.49 & 150.00 & 76.81 & 199.15 & 71.56 & 0.08 \\
\hline 12 & 2.88 & 147.99 & 10.28 & 150.00 & 77.55 & 199.63 & 105.00 & 0.06 \\
\hline 13 & 3.21 & 148.55 & 9.56 & 150.00 & 68.92 & 199.27 & 103.46 & 0.06 \\
\hline 14 & 521.29 & 148.24 & 9.96 & 141.54 & 68.76 & 199.39 & 109.50 & 10.43 \\
\hline 15 & 303.96 & 148.22 & 8.97 & 142.08 & 70.41 & 199.32 & 70.65 & 6.08 \\
\hline 17 & 1.50 & 148.31 & 10.00 & 147.92 & 65.48 & 199.51 & 101.63 & 0.03 \\
\hline 18 & 39628.85 & 144.66 & 8.83 & 134.23 & 28.89 & 1153.92 & 117.42 & 792.58 \\
\hline 19 & 26975.00 & 149.65 & 1.67 & 150.00 & 55.10 & 1227.50 & 125.00 & 539.50 \\
\hline 20 & 22903.85 & 147.97 & 9.54 & 139.23 & 43.96 & 1164.62 & 43.50 & 458.08 \\
\hline 21 & 133745.83 & 118.75 & 242.75 & 51.25 & 5010.71 & 752.58 & 1554.50 & 2674.92 \\
\hline
\end{tabular}


Table 8. Continued.

\begin{tabular}{|c|c|c|c|c|c|c|c|c|}
\hline Station & $\mathbf{W i} \times \mathbf{Q} \mathbf{i}-\mathbf{Z n}$ & $\mathbf{W i} \times \mathbf{Q} \mathbf{i}-\mathbf{P b}$ & Wi $\times \mathbf{Q i}-\mathrm{Cd}$ & $\mathbf{W i} \times \mathbf{Q i}-\mathbf{C r}$ & $\mathbf{W i} \times \mathbf{Q} \mathbf{i}-\mathbf{C u}$ & Wi $\times \mathbf{Q i}-\mathbf{M n}$ & $\Sigma \mathbf{W i} \times \mathbf{Q i}$ & HPI \\
\hline 1 & 0.03 & 6.14 & 44.40 & 1.29 & 0.20 & 2.03 & 56.99 & 53.71 \\
\hline 2 & 0.03 & 5.20 & 42.00 & 1.06 & 0.63 & 2.20 & 213.87 & 201.54 \\
\hline 3 & 0.03 & 6.35 & 44.19 & 0.91 & 0.09 & 0.74 & 235.38 & 221.81 \\
\hline 4 & 0.03 & 5.40 & 45.00 & 1.40 & 0.20 & 0.88 & 55.15 & 51.97 \\
\hline 5 & 0.03 & 5.73 & 42.94 & 1.28 & 0.20 & 2.15 & 66.52 & 62.68 \\
\hline 6 & 0.03 & 6.07 & 43.88 & 0.52 & 0.20 & 2.16 & 53.09 & 50.03 \\
\hline 7 & 0.03 & 5.52 & 42.00 & 0.35 & 0.20 & 1.94 & 51.11 & 48.16 \\
\hline 8 & 0.03 & 6.55 & 44.70 & 1.43 & 0.20 & 2.22 & 61.94 & 58.37 \\
\hline 9 & 0.03 & 6.40 & 41.38 & 0.63 & 0.20 & 2.13 & 83.12 & 78.32 \\
\hline 10 & 0.03 & 6.94 & 44.25 & 1.82 & 0.20 & 52.00 & 437.24 & 412.02 \\
\hline 11 & 0.03 & 5.95 & 45.00 & 1.54 & 0.20 & 1.43 & 54.22 & 51.10 \\
\hline 12 & 0.03 & 7.19 & 45.00 & 1.55 & 0.20 & 2.10 & 56.13 & 52.90 \\
\hline 13 & 0.03 & 6.69 & 45.00 & 1.38 & 0.20 & 2.07 & 55.44 & 52.24 \\
\hline 14 & 0.03 & 6.97 & 42.46 & 1.38 & 0.20 & 2.19 & 63.65 & 59.98 \\
\hline 15 & 0.03 & 6.28 & 42.63 & 1.41 & 0.20 & 1.41 & 58.03 & 54.69 \\
\hline 16 & 0.03 & 6.18 & 42.75 & 1.37 & 0.20 & 0.51 & 55.85 & 52.63 \\
\hline 17 & 0.03 & 7.00 & 44.38 & 1.31 & 0.20 & 2.03 & 54.98 & 51.81 \\
\hline 18 & 0.03 & 6.18 & 40.27 & 0.58 & 1.15 & 2.35 & 843.14 & 794.51 \\
\hline 19 & 0.03 & 1.17 & 45.00 & 1.10 & 1.23 & 2.50 & 590.53 & 556.47 \\
\hline 20 & 0.03 & 6.68 & 41.77 & 0.88 & 1.16 & 0.87 & 509.47 & 480.09 \\
\hline 21 & 0.02 & 169.93 & 15.38 & 100.21 & 0.75 & 31.09 & 2992.30 & 719.73 \\
\hline
\end{tabular}

The HPI values of groundwater ranged from 48.56 to 72.49 (Table 9). All groundwater-sampling sites have HPI values below the critical HPI limit value (Figure 5). It shows, in general, that the groundwater samples are not contaminated with respect to heavy metals pollution.

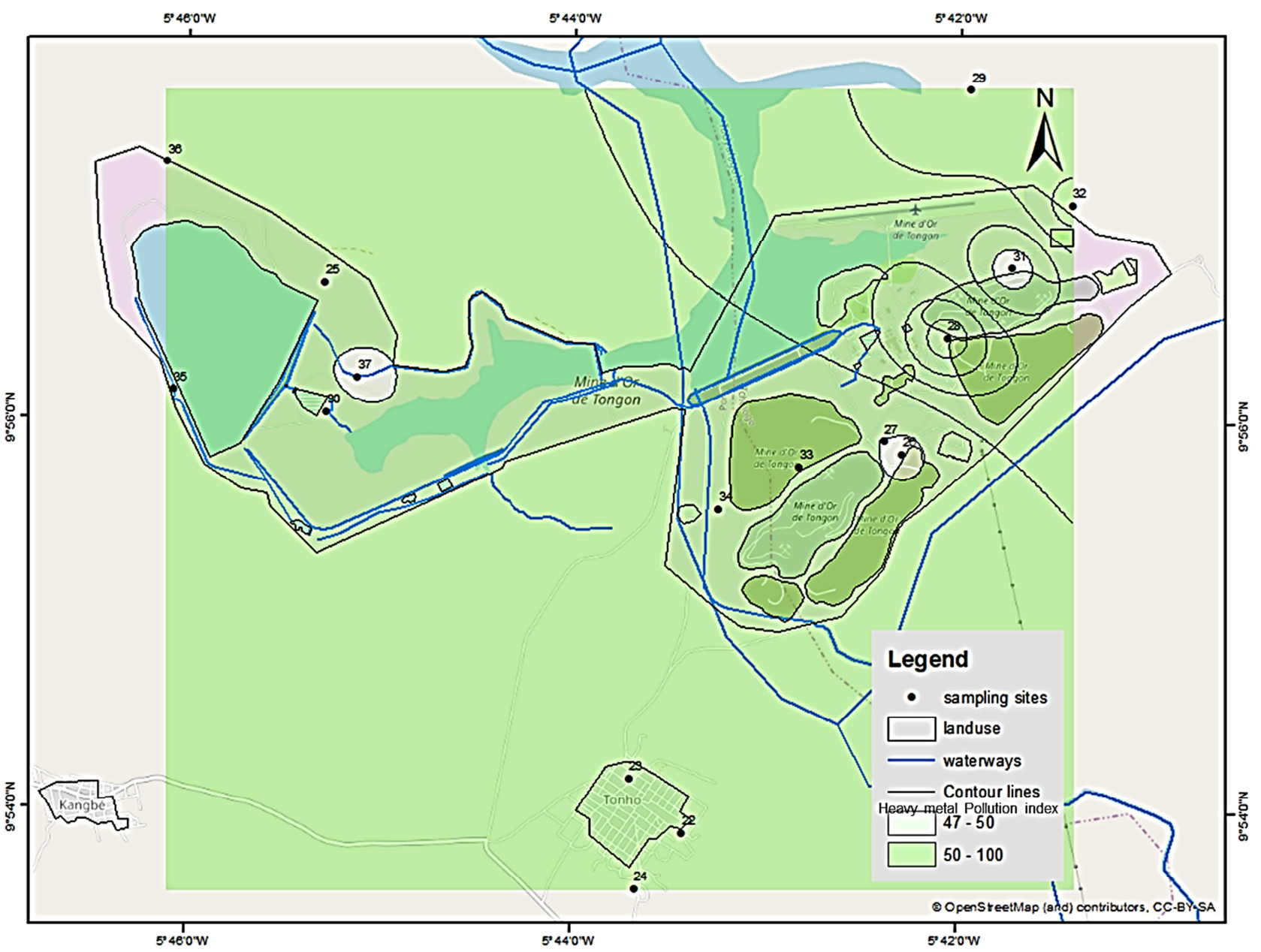

Figure 5. HPI map of groundwater around Tongon mine. 
Table 9. Heavy metal pollution index of groundwater sampling stations.

\begin{tabular}{|c|c|c|c|c|c|c|c|c|}
\hline Station & Qi-As & Qi-Zn & Qi-Pb & Qi-Cd & Qi-Cr & Qi-Cu & Qi-Mn & Wi $\times$ Qi-As \\
\hline 22 & 9.67 & 148.53 & 8.38 & 149.23 & 66.56 & 198.36 & 100.95 & 0.19 \\
\hline 23 & 19.67 & 149.07 & 8.17 & 149.23 & 66.88 & 199.14 & 96.80 & 0.39 \\
\hline 24 & 17.25 & 148.86 & 8.97 & 149.38 & 65.31 & 199.34 & 59.68 & 0.35 \\
\hline 25 & 9.63 & 148.84 & 2.85 & 149.17 & 66.67 & 197.67 & 493.50 & 0.19 \\
\hline 26 & 34.90 & 146.46 & 4.97 & 149.62 & 32.65 & 199.15 & 106.38 & 0.70 \\
\hline 27 & 16.06 & 148.31 & 8.61 & 148.13 & 54.34 & 198.98 & 46.95 & 0.32 \\
\hline 28 & 633.27 & 148.30 & 27.10 & 140.38 & 19.94 & 180.19 & 128.25 & 12.67 \\
\hline 30 & 21.15 & 147.08 & 9.49 & 150.00 & 66.16 & 199.08 & 122.93 & 0.42 \\
\hline 31 & 37.71 & 147.74 & 2.70 & 149.58 & 60.88 & 198.73 & 96.64 & 0.75 \\
\hline 32 & 169.02 & 147.76 & 4.98 & 148.64 & 62.15 & 198.67 & 881.25 & 3.38 \\
\hline 33 & 17.37 & 148.33 & 9.12 & 150.00 & 66.25 & 199.26 & 121.55 & 0.35 \\
\hline 34 & 3.13 & 148.50 & 8.24 & 150.00 & 67.01 & 199.08 & 122.58 & 0.06 \\
\hline 35 & 12.58 & 147.93 & 9.67 & 149.17 & 63.61 & 199.49 & 57.80 & 0.25 \\
\hline 36 & 2.83 & 148.35 & 6.96 & 149.23 & 64.68 & 199.12 & 119.78 & 0.06 \\
\hline 37 & 7.44 & 148.91 & 3.77 & 150.00 & 67.19 & 199.37 & 108.75 & 0.15 \\
\hline
\end{tabular}

Table 9. Continued.

\begin{tabular}{|c|c|c|c|c|c|c|c|c|}
\hline Station & $\mathbf{W i} \times \mathbf{Q i - Z n}$ & $\mathbf{W i} \times \mathbf{Q i}-\mathbf{P b}$ & Wi $\times Q i-C d$ & Wi $\times$ Qi-Cr & $\mathrm{Wi} \times \mathbf{Q i}-\mathrm{Cu}$ & Wi×Qi-Mn & $\mathbf{\Sigma W i} \times \mathbf{Q i}$ & HPI \\
\hline 22 & 0.03 & 5.87 & 44.77 & 1.33 & 0.20 & 2.02 & 54.41 & 51.27 \\
\hline 23 & 0.03 & 5.72 & 44.77 & 1.34 & 0.20 & 1.94 & 54.38 & 51.25 \\
\hline 24 & 0.03 & 6.28 & 44.81 & 1.31 & 0.20 & 1.19 & 54.17 & 51.04 \\
\hline 26 & 0.03 & 3.48 & 44.88 & 0.65 & 0.20 & 2.13 & 52.07 & 49.07 \\
\hline 27 & 0.03 & 6.03 & 44.44 & 1.09 & 0.20 & 0.94 & 53.04 & 49.98 \\
\hline 28 & 0.03 & 18.97 & 42.12 & 0.40 & 0.18 & 2.57 & 76.93 & 72.49 \\
\hline 30 & 0.03 & 6.64 & 45.00 & 1.32 & 0.20 & 2.46 & 56.08 & 52.84 \\
\hline 31 & 0.03 & 1.89 & 44.88 & 1.22 & 0.20 & 1.93 & 50.90 & 47.97 \\
\hline 32 & 0.03 & 3.49 & 44.59 & 1.24 & 0.20 & 17.63 & 70.55 & 66.48 \\
\hline 33 & 0.03 & 6.38 & 45.00 & 1.32 & 0.20 & 2.43 & 55.72 & 52.50 \\
\hline 34 & 0.03 & 5.77 & 45.00 & 1.34 & 0.20 & 2.45 & 54.85 & 51.69 \\
\hline 35 & 0.03 & 6.77 & 44.75 & 1.27 & 0.20 & 1.16 & 54.43 & 51.29 \\
\hline 36 & 0.03 & 4.87 & 44.77 & 1.29 & 0.20 & 2.40 & 53.61 & 50.52 \\
\hline 37 & 0.03 & 2.64 & 45.00 & 1.34 & 0.20 & 2.18 & 51.54 & 48.56 \\
\hline
\end{tabular}

\section{Conclusion}

In this research, the heavy metal concentrations were first evaluated, and then a Heavy Metal Pollution Index was calculated for surface water and groundwater around the Tongon gold mine. The findings of the present research are summarized as follows:

i. The concentration of $\mathrm{As}, \mathrm{Pb}, \mathrm{Cr}, \mathrm{Cu}$ and $\mathrm{Mn}$ has been found more than the highest desirable limit of WHO drinking water standard in the majority of sampling stations for surface water.

ii. The surface water of the sampling site, which has the HPI values above the critical index value of 100 was used by the water reusing system of the mine.

iii. In general, the groundwater is not contaminated with respect to heavy metals pollution.

\section{Acknowledgements}

The authors want to thank authorities of Tongon gold mine for their support for this study. Thanks to Dr Julien Bahino in atmospheric physics laboratory of FHB University, Abidjan, Côte d'Ivoire, for their help and suggestions to the draft manuscript.

\section{References}

[1] Dorleku, M. K., Nukpezah, D., Carboo, D. Effects of Smallscale Gold Mining on Heavy Metal Levels in Groundwater in the Lower Pra Basin of Ghana. Applied Water Science. Vol. 8, No 5, 2018, p. 126

[2] Bempah, C. K., \& Ewusi, A. Heavy Metals Contamination and Human Health Risk Assessment around Obuasi Gold Mine in Ghana. Environmental Monitoring and Assessment. Vol. 188, No 5, 2016, p. 261.

[3] Kouakou Adjoumani Rodrigue, N., Yao, B. K., Trokourey, A., \& Adouby, K. Heavy Metals in Sediments and Their Transfer to Edible Mollusc. Journal of Applied Sciences. Vol. 16, No. 11, 2016, pp. 534-541.

[4] Rodrigue, K. A., Yao, B., Trokourey, A., \& Kopoin, A. Assessment of Heavy Metals Contamination in Sediments of the Vridi Canal (Côte d'Ivoire). Journal of Geoscience and Environment Protection. Vol. 4, No. 10, 2016, p. 65.

[5] Ning, L., Liyuan, Y., Jirui, D., \& Xugui, P. Heavy Metal Pollution in Surface Water of Linglong Gold Mining Area, China. Procedia Environmental Sciences. Vol. 10, 2011, pp. 914-917. 
[6] Vetrimurugan, E., Brindha, K., Elango, L., \& Ndwandwe, O. M. Human Exposure Risk to Heavy Metals Through Groundwater Used for Drinking in an Intensively Irrigated River Delta. Applied Water Science. Vol. 7, No 6, 2017, pp. 3267-3280.

[7] El-Hamid, H. T. A., \& Hegazy, T. A. Evaluation of Water Quality Pollution Indices for Groundwater Resources of New Damietta, Egypt. MOJ Ecology Environmental Science. Vol. 2, No 6, 2017, p. 00045.

[8] Jaishankar, M., Tseten, T., Anbalagan, N., Mathew, B. B., \& Beeregowda, K. N. Toxicity, Mechanism and Health Effects of Some Heavy Metals. Interdisciplinary Toxicology. Vol. 7, No 2, 2014, pp. 60-72.

[9] Prasad, B., Kumari, P., Bano, S., \& Kumari, S. Ground Water Quality Evaluation near Mining Area and Development of Heavy Metal Pollution Index. Applied Water Science. Vol. 4, No 1, 2014, pp. 11-17.

[10] FAIR LINKS 2013: Rapport de l'Administrateur indépendant de l'Initiative pour la Transparence des Industries Extractives (ITIE) pour les revenus de l'année 2011, Côte d'Ivoire. https://eiti.org/sites/default/files/documents/Cote_dIvoire/CA C75-Rapport-de-Validation-ITIE-Cote-d\%27Ivoire-2013FR.pdf.

[11] Koffi, Y. A., Ahoussi, K. E., Kouassi, M. A., \& Biemi, J. (2014). Ressources minières, pétrolières et gazières de la Côte d'Ivoire et problématique de la pollution des ressources en eau et des inondations. International Journal of Tropical Ecology and Geography. Vol. 38, no 1, 2014 p. 119-136.

[12] APHA. Standard Methods for the Examination of Water and Waste Water. APHA, Washington, D. C., U. S. A, 2002.
[13] Saleh, H. N., Panahande, M., Yousefi, M., Asghari, F. B., Conti, G. O., Talaee, E., \& Mohammadi, A. A. Carcinogenic and Non-Carcinogenic Risk Assessment of Heavy Metals in Groundwater Wells in Neyshabur Plain, Iran. Biological Trace Element Research. Vol. 190, No 1, 2019, pp. 251-261.

[14] Mativenga, P. T., \& Marnewick, A. (2018). Water Quality in a Mining And Water-Stressed Region. Journal of Cleaner Production. Vol. 171, 2018, pp. 446-456.

[15] Tiwari, A. K., De Maio, M., Singh, P. K., \& Mahato, M. K. (2015). Evaluation of Surface Water Quality by Using GIS and a Heavy Metal Pollution Index (HPI) Model in a Coal Mining Area, India. Bulletin of Environmental Contamination and Toxicology. Vol. 95, No 3, 2015, pp. 304-310.

[16] Naminata, S., Kwa-Koffi, K. E., Marcel, K. A., \& Marcellin, Y. K. Assessment and Impact of Leachate Generated by the Landfill City in Abidjan on the Quality of Ground Water and Surface Water (M'Badon Bay, Côte d'Ivoire). Journal of Water Resource and Protection. Vol. 10, No. 3, 2018, pp. 145165.

[17] Bakary, I., Yao, K. M., Etchian, O. A., Soro, M. B., Trokourey, A., \& Bokra, Y. Zinc, copper, cadmium, and lead concentrations in water, sediment, and Anadara senilis in a tropical estuary. Environmental monitoring and assessment. Vol. 187, No. 12, 2015, p. 762.

[18] Coulibaly, S., Atse, B. C., Koffi, K. M., Sylla, S., \& Konan, K. J. Seasonal accumulations of some heavy metal in water, sediment and tissues of black-chinned tilapia Sarotherodon melanotheron from Biétri Bay in Ebrié Lagoon, Ivory Coast. Bulletin of environmental contamination and toxicology. Vol. 88, No. 4, 2012, pp. 571-576. 